Niniejsza publikacja jest dostępna na licencji Creative Commons. Uznanie autorstwa-Użycie niekomercyjne-Bez utworów zależnych 3.0 Polska. Pewne prawa zastrzeżone na rzecz autora. Zezwala się na wykorzystanie publikacji zgodnie z licencja - pod warunkiem zachowania niniejszej informacji licencyjnej oraz wskazania autora jako właściciela praw do tekstu. Treść licencji jest dostępna na stronie: http://creativecommons.org/licenses/by-nc-nd/3.0/pl/

Lingwistyka Stosowana 20: 5/2016, 19-30

\author{
Anna BONEK \\ Uniwersytet Warszawski
}

\title{
Ergonomizacja procesu tłumaczenia pisemnego. Wyniki badania okulograficznego
}

\begin{abstract}
:
Ergonomization of translation processes: Eye-tracking study.

The Eye-Tracking Experimental Linguistics Laboratory conducted an eye-tracking study on the translation of German administrative acts translated into Polish, engaging a group of five participants. The aim of the study was to identify critical factors which may slow down the translation process and affect the quality of the translation. Research method: The study was carried out with the SMI RED 500 eyetracker and utilized the method of dynamic areas of interest, which allowed the participants to freely move the windows on the monitor and use a PDF document, a text editor and a web browser at the same time. Results: If the source-language text contained numbers and special characters, the speed of the target-language text production considerably decreased. No correlation was found between the keyboard fixation duration at the time of the target text production and the translation speed. Placing the text editor on the right-hand side of the monitor and locating both the source text and the web browser on the lefthand side of the screen helped reduce the number of unnecessary computer mouse movements. The target-language text formatting comprised from 8 to $30 \%$ of the total translation time, with the time of the proper text arrangement performed after the completion of the translation being shorter than that of carried out while translating the source text. Conclusions: Numbers and special character typing skills, use of local and language content filters and comprehensive knowledge of text formatting options of text editors may significantly facilitate the translation process and develop "computer competence" of translators. Moreover, it is necessary to develop a list of reliable Internet sources for translators and effective search strategies for translation equivalents.
\end{abstract}

\section{Wstęp ${ }^{1}$}

W roku akademickim 2014/2015 w Laboratorium Eksperymentalnej Lingwistyki Okulograficznej (LELO) ${ }^{2}$ Instytutu Komunikacji Specjalistycznej i Interkulturowej (Uniwersytet Warszawski) przeprowadzono badanie okulograficzne procesu tłumaczenia pisemnego niemieckich aktów administracyjnych na język polski. Tłumaczenie wykonywane było na komputerze zintegrowanym z okulografem. Celem badania była analiza procesu tłumaczenia pisemnego tekstów specjalistycznych pod kątem jego ergonomizacji (usprawnienia).

${ }^{1}$ W tym miejscu pragnę serdecznie podziękować Panu Profesorowi Samborowi Gruczy za wszelką pomoc okazaną podczas sporządzania niniejszego artykułu.

${ }^{2}$ http://www.lelo.uw.edu.pl/ (29.09.2016). 
Podstawę teoretyczną badania oraz dalszych rozważań stanowiła antropocentryczna teoria języków specjalistycznych S. Gruczy oraz translatoryka antropocentryczna F. Gruczy i S. Gruczy. Tłumacz (mówca-słuchacz) wraz z umiejscowionymi w mózgu właściwościami translacyjnymi oraz zachodzącymi w jego mózgu operacjami translacyjnymi staje w centrum zainteresowania rozważań translacyjnych (por. S. Grucza 2014: 127). Badania okulograficzne licznie stosowane obecnie w translatoryce przyczyniły się do pozyskania nowej, a także do weryfikacji obecnej wiedzy dotyczącej kompetencji translacyjnych (por. m. in. S. Grucza 2014, M. Płużyczka 2015, S. Göpferich 2008, A. Bonek 2017). Podstawą stosowania okulografu w badaniach translacyjnych stało się przekonanie, że ruchy gałek ocznych sterowane są procesami mentalnymi (kognitywnymi), które zachodzą w mózgu danej osoby, co powinno umożliwić rekonstrukcję tych procesów (por. m.in. S. Grucza 2011: 157, N. Pavlović/ K.T.H. Jensen 2009: 94). M.A. Just i P.A. Carpenter w 1980 r. sformułowali hipotezę dotyczącą powiązania długości fiksacji oka na wyrazie z długością jego przetwarzania przez osobę badaną ${ }^{3}$.

Badania okulograficzne stosowane do tej pory przy analizie thumaczenia pisemnego realizowane były przy pomocy oprogramowania Translog (np. Š. Timarová/ B. Dragsted/ G. Hansen 2011), co uniemożliwiało przeprowadzenie badania procesu tłumaczenia w warunkach naturalnych dla thumacza i z wykorzystaniem znajomego interfejsu, czyli edytora tekstu, przeglądarki internetowej, a także tekstu wyjściowego w formacie PDF. Użycie programu Translog wymuszało na osobach badanych wykonywanie thumaczenia w nieznanym programie, czyli warunkach nie odpowiadających przyzwyczajeniom tłumaczy, co mogło mieć znaczny wpływ na ruchy gałek ocznych badanych. Do tej pory przeprowadzono również badania okulograficzne procesu tłumaczenia pisemnego wykonywanego w programach dedykowanych dla thumaczy SDL Trados oraz Across (np. Sh. O’Brien 2006). Na chwilę obecną nie są mi znane badania okulograficzne procesu tłumaczenia pisemnego przeprowadzone $\mathrm{z}$ użyciem metody dynamicznych obszarów zainteresowania z zastosowaniem trzech okien roboczych (tekstu wyjściowego, tekstu docelowego oraz przeglądarki internetowej). Mimo nieustającego rozprzestrzenienia się oprogramowania dedykowanego tłumaczom nadal rozpowszechniony pozostaje tradycyjny sposób wykorzystywania wyżej wymienionych trzech programów jednocześnie. Potrzebę wdrożenia tego typu badań umożliwiających analizę ruchów gałek ocznych podczas obsługi okien roboczych przez tłumacza zasygnalizowała S. Göpferich (2008).

Celem badania okulograficznego procesu tłumaczenia wspomaganego komputerowo był:

1) pomiar ruchów gałek ocznych podczas recepcji tekstu wyjściowego, tekstu docelowy oraz przeglądarki internetowej;

2) ustalenie związku pomiędzy szybkością pisania na klawiaturze a czasem tłumaczenia;

\footnotetext{
${ }^{3}$ Badania okulograficzne procesu tłumaczenia a vista prowadzone przez M. Płużyczkę w 2015 r. częściowo podważyły te założenia dowodząc, że przestrzenne ruchy sakadowe świadczyć mogą o przetwarzaniu kognitywnym podczas tłumaczenia a vista.
} 
3) sprawdzenie wpływu rozkładu uwagi wzrokowej pomiędzy klawiaturą a monitorem na czas thumaczenia;

4) ustalenie optymalnego układu okien roboczych na monitorze podczas tłumaczenia;

5) wpływ odzwierciedlania formatowania w tekście docelowym na czas tłumaczenia.

Sposób korzystania przez osoby badane z przeglądarki internetowej znalazł się również w centrum zainteresowania niniejszych badań. Uwaga była poświęcona również ruchom gałek ocznych studentów podczas wyszukiwania poprawnego thumaczenia niemieckich wyrazów w źródłach internetowych w celu zrozumienia, czym osoby badane kierowały się najczęściej przy wyborze źródła internetowego.

\section{Opis badania}

W badaniu uczestniczyło pięć studentów ostatniego roku studiów magisterskich na kierunku tłumaczenia specjalistyczne w Instytucie Komunikacji Specjalistycznej i Interkulturowej Uniwersytetu Warszawskiego. Każdy student miał za zadanie przetłumaczyć decyzję o przyjęciu na studia wyższe w Niemczech z języka niemieckiego na język polski. Średni czas tłumaczenia dla wszystkich pięciu osób wyniósł ok. 40 minut. Badanie przeprowadzono w Laboratorium Eksperymentalnej Lingwistyki Stosowanej, w którym podczas tłumaczenia znajdowała się osoba badana oraz osoba nadzorująca badanie. Pomieszczenie było odizolowane od osób postronnych. Studenci byli obeznani z tego rodzaju tekstami, gdyż podobne decyzje administracyjne były tłumaczone $\mathrm{z}$ nimi w czasie trwania semestru akademickiego. Ponadto przed badaniem studenci zostali pouczeni o tym, że ich tłumaczenie nie będzie uwzględniane w ich ocenie końcowej. W czasie tłumaczenia do dyspozycji były zarówno słownik drukowany dwujęzyczny (Słownik ekonomiczny i prawniczy A. Kilian i A. Kilian) oraz Internet. Badania okulograficzne wspomagane były nagraniami wideo oraz audio. Czas tłumaczenia był nieograniczony. Studenci mogli dowolnie przesuwać okna robocze na monitorze (tekst wyjściowy - format PDF, tekst docelowy - program WordPad, przeglądarka internetowa - Mozilla Firefox). Polecenie brzmiało: „Proszę zapoznać się z tekstem, zaś następnie go przetłumaczyć"4. Studenci wykonywali tłumaczenie na monitorze o przekątnej 22 ". W badaniu użyto okulografu firmy SMI typu RED500. Częstotliwość próbkowania wyniosła $60 \mathrm{~Hz}^{5}$. Odległość od oczu badanych od monitora wynosiła ok. 50-70 cm, maksymalne odchylenie pomiaru $<0,4^{\circ}$, latencja (end to end): $<10 \mathrm{~ms}$, obszar śledzenia $40^{\circ} \mathrm{W}$ poziomie $\left( \pm 20^{\circ}\right), 60^{\circ} \mathrm{W}$ pionie $(+20 /-$ $\left.40^{\circ}\right)$. Dane uzyskane w procesie badania okulograficznego były analizowane w programie BeGaze z zastosowaniem metody dynamicznych obszarów zainteresowania (por. K. Holmqvist i in. 2011: 209).

\footnotetext{
${ }^{4}$ Ogólny sposób sformułowania polecenia miał za zadanie sprawdzić, czy studenci zwrócą się za dodatkową informacją uszczegółowiającą cel lub odbiorcę tekstu docelowego.

${ }^{5}$ Częstotliwość próbkowania została wybrana ze względu na długi czas badania (209 minut) oraz towarzyszące badaniu nagrania audio i video, które znacznie spowolniły czas przetwarzania danych podczas analizy wyników badania.
} 


\section{Wyniki badania}

W wyniku całościowej analizy nagrań z monitora komputera połączonych z analizą ruchów gałek ocznych, a także nagraniami wideo dokonano analizy rozkładu uwagi pomiędzy oknami roboczymi na monitorze komputera oraz zbadano kilka czynników mogących wpływać na całościowy czas wykonania tłumaczenia. Przedmiotem analizy był: 1) rozkład uwagi studentów pomiędzy oknami roboczymi na monitorze (tekst wyjściowy, tekst docelowy, przeglądarka internetowa), 2) szybkość pisania na klawiaturze, 3) rozkład uwagi wzrokowej pomiędzy monitorem a klawiaturą w czasie wykonywania tłumaczenia, 4) optymalny układ okien roboczych na monitorze, 5) czas formatowania w tekście docelowym i czas tłumaczenia oraz 6) sposób wyszukiwania źródeł internetowych w przeglądarce internetowej.

\subsection{Rozkład uwagi studentów pomiędzy oknami roboczymi na monitorze}

W celu zbadania rozkładu uwagi wzrokowej pomiędzy oknami roboczymi używanymi przez studentów na monitorze (tekst wyjściowy, tekst docelowy, przeglądarka internetowa) zdefiniowano trzy obszary zainteresowania. Analiza okulograficzna procesu tłumaczenia przeprowadzona w programie BeGaze umożliwiła wyliczenie oraz zestawienia czasu fiksacji, liczby fiksacji oraz czasu fiksacji i sakad podczas recepcji trzech okien roboczych zdefiniowanych, jako obszary zainteresowania (Areas of Interests). Z powodu niejednorodności kolorystycznej okien roboczych, a stron wyświetlanych w przeglądarce internetowej parametr szerokości źrenicy nie był uwzględniony w badaniach. Wybór użytych w niniejszym badaniu parametrów (długość fiksacji, liczba fiksacji, czas fiksacji i sakad) uzasadniony jest wynikami badań okulograficznych $\mathrm{w}$ translatoryce przeprowadzonych przez m.in. V.C.Y. Chang (2011), A.C. Sjørup (2011) oraz M. Płużyczka (2015).

\begin{tabular}{|l|c|c|c|c|c|c|c|c|c|}
\hline Osoba & $\begin{array}{c}\text { czas } \\
\text { fiksacji } \\
{[\mathrm{ms}]} \\
\text { TW }\end{array}$ & $\begin{array}{c}\text { czas } \\
\text { fiksacji } \\
{[\mathrm{ms}]} \\
\text { TD }\end{array}$ & $\begin{array}{c}\text { czas } \\
\text { fiksacji } \\
{[\mathrm{ms}]} \\
@\end{array}$ & $\begin{array}{c}\text { Liczba } \\
\text { fiksacji } \\
\text { TW }\end{array}$ & $\begin{array}{c}\text { Liczba } \\
\text { fiksacji } \\
\text { TD }\end{array}$ & $\begin{array}{c}\text { Liczba } \\
\text { fiksacji } \\
@\end{array}$ & $\begin{array}{c}\text { Czas } \\
\text { fiksacji i } \\
\text { sakad } \\
{[\mathrm{ms}]} \\
\text { TW }\end{array}$ & $\begin{array}{c}\text { Czas } \\
\text { fiksacji i } \\
\text { sakad } \\
{[\mathrm{ms}]} \\
\text { TD }\end{array}$ & $\begin{array}{c}\text { Czas } \\
\text { fiksacji i } \\
\text { sakad } \\
{[\mathrm{ms}]} \\
@\end{array}$ \\
\hline P01 & 242587 & $\underline{537945,2}$ & 404154,1 & 757 & 1105 & $\underline{1154}$ & 260430,1 & $\underline{563089}$ & 436068,1 \\
\hline P02 & 492929 & $\underline{956379,8}$ & 474220,2 & 1487 & $\underline{2830}$ & 1378 & 560372,2 & $\underline{1087626}$ & 528933,9 \\
\hline P03 & 84338,9 & $\underline{270444,7}$ & 34451,2 & 540 & $\underline{1380}$ & 200 & 142385 & $\underline{470506}$ & 82110,8 \\
\hline P04 & 338429 & $\underline{544395,9}$ & 161895 & 967 & $\underline{1342}$ & 435 & 359536,5 & $\underline{572190}$ & 172964,1 \\
\hline P05 & 198725 & $\underline{494521,4}$ & 314046,1 & 731 & $\underline{1591}$ & 1061 & 217030,5 & $\underline{564017}$ & 346549 \\
\hline
\end{tabular}

Tabela 1. Rozkład czasu fiksacji (fixation duration), liczby fiksacji (fixation count) oraz czasu fiksacji i sakad (dwell time) podczas recepcji tekstu wyjściowego (TW), tekstu docelowego (TD) oraz przeglądarki internetowej (@). 
Z tabeli nr 1 wynika, że pięć osób badanych najwięcej uwagi pośród trzech obszarów zainteresowania poświęcili edytorowi tekstu WordPad ${ }^{6}$. Wynik ten oznacza, że największe obciążenie kognitywne ${ }^{7}$ towarzyszyło produkcji tekstu docelowego. Studenci poświęcili najwięcej czasu produkcji tekstu. Powyższe parametry wybrano bazując na założeniach M. A. Justa i P. A. Carpentera z 1980 r. (fixation duration, fixation count) oraz M. Płużyczki z 2015 r. (dwell time) uwzględniając w badaniach ruchy sakadowe. Za wyjątkiem jednego przypadku (szósta kolumna drugi wiersz) wszystkie trzy parametry osiągnęły najwyższe wartości podczas recepcji tekstu docelowego. Niniejsze wnioski ukierunkowały dalsze pytania badawcze w niniejszym artykule w stronę szczegółowej analizy procesu produkcji tekstu docelowego. Rozszerzenie grupy badawczej do piętnastu osób oraz statystyczna analiza obszarów roboczych angażujących największą oraz najmniejszą pracę kognitywną podczas ich recepcji znajduje się w A. Bonek (2017).

\subsection{Szybkość pisania na klawiaturze}

W niniejszym punkcie przedstawię wyniki analizy szybkości produkcji tekstu docelowego podczas thumaczenia. Niniejsze wyniki uzyskano analizując nagrania z monitoru (screen recording) porównując nagranie ze ścieżką nagrania ukazującą wszystkie uderzenia klawiatury oraz kliknięcia myszką podczas procesu tłumaczenia. Szybkość pisania badanych na klawiaturze była mierzona kierując się nagraniami z monitora (screen recording) oraz ze ścieżki rejestrującej uderzenia na klawiaturze. Stwierdzono, że produkcja tekstu następuje w sekwencjach składających się co do zasady z recepcji fragmentu tekstu wyjściowego, następczej produkcji jednostki tekstu wyjściowego oraz następczej kontrolnej recepcji tekstu docelowego. Zauważono, że zarówno długość, jak i prędkość produkcji fragmentów tekstu docelowego różni się w zależności od osoby badanej. Czas produkcji tekstu w czasie sekwencji związanej z produkcją tekstu był odnotowywany. Następnie zauważono, że czas produkcji tekstu docelowego znacznie się wydłuża, jeśli w jednostce produkowanego tekstu pojawiają się liczby lub znaki szczególne typu: „,/, -, - ”.

\begin{tabular}{|c|c|c|}
\hline osoba & $\begin{array}{r}\text { Średni czas produkcji frag- } \\
\text { mentu tekstu bez znaków szczegól- } \\
\text { nych i liczb }[\mathrm{s}]\end{array}$ & $\begin{array}{r}\text { Sredni czas produkcji fragmen- } \\
\text { tu tekstu ze znakami szczególnymi i } \\
\text { liczbami [s] }\end{array}$ \\
\hline P01 & 10,0 & 39,0 \\
\hline P02 & 40,0 & 19,0 \\
\hline P03 & 8,6 & 21,0 \\
\hline P04 & 9,7 & 17,5 \\
\hline P05 & 7,0 & 22,0 \\
\hline
\end{tabular}

Tabela 2. Średni czas produkcji fragmentu tekstu docelowego zawierającej znaki szczególne oraz bez takich znaków.

${ }^{6} \mathrm{Z}$ powodu małej liczby osób badanych oraz porównywanych liczb zrezygnowano w niniejszym artykule z przeprowadzenia wyliczeń statystycznych.

${ }^{7}$ Odnośnie różnicy pomiędzy obciążeniem kognitywnym a pracą kognitywną patrz M. Płużyczka (2015). 
Z tabeli Nr 2 wynika, że wśród czterech badanych pojawianie się w czasie produkcji tekstu docelowego znaków szczególnych w tekście wyjściowym spowalniało w znacznym stopniu produkcję tekstu docelowego. U pierwszej osoby szybkość wpisywania fragmentu tekstu docelowego spadła prawie czterokrotnie. Wśród pozostałych trzech osób szybkość produkcji tekstu zmniejszała się prawie dwukrotnie. Odnotowany stan rzeczy wynikać może z tego, że studenci sprawniej posługiwali się klawiaturą zawierającą litery niż znaki szczególne bądź liczby. Można wysnuć wniosek sugerujący, że sprawniejsze opanowanie klawiatury komputera prowadzić może do zwiększenia całkowitego czasu wykonywania tłumaczenia.

\subsection{Rozkład uwagi wzrokowej pomiędzy monitorem a klawiaturą w czasie wy- konywania thumaczenia}

W mniejszym punkcie przedstawione będą wyniki analizy rozkładu uwagi wzrokowej pomiędzy monitorem a klawiaturą podczas procesu tłumaczenia. Ponadto otrzymany czas skupienia uwagi na klawiaturze zostanie porównany z czasem całkowitym tłumaczenia u poszczególnych osób. W ten sposób sprawdzone będzie istnienie zależności pomiędzy długością spoglądania na klawiaturę podczas produkcji tekstu a szybkością tłumaczenia. Tego rodzaju badanie może pomóc wysnuć wnioski dotyczące wpływu pisania bezwzrokowego na czas tłumaczenia.

\begin{tabular}{|c|c|}
\hline $\begin{array}{c}\text { Czas spoglądania na } \\
\text { klawiature podczas produkcji } \\
\text { tekstu docelowego [s] }\end{array}$ & $\begin{array}{c}\text { Całkowity czas thuma- } \\
\text { czenia [s] }\end{array}$ \\
\hline 204127 & 3107264 (ok. 51 minut) \\
\hline 504162 & 1754892 (ok. 29 minut) \\
\hline 542975 & 1968936 (ok. 32 minut) \\
\hline 667108 & 2218283 (ok. 36 minut) \\
\hline 1191471 & 3682309 (ok. 61 minut) \\
\hline
\end{tabular}

Tabela 3. Czas spoglądania na klawiaturę podczas produkcji tekstu docelowego.

Dane z tabeli Nr 3 uzyskane zostały na podstawie obserwacji nagrań z monitoru screen recording, nagrań ścieżki wzroku oraz nagrań wideo. Czas był mierzony podczas spoglądania na klawiaturę w celu produkcji tekstu docelowego. Na podstawie rosnącego ułożenia wyników w prawej kolumnie (z wyjątkiem pierwszego wiersza) otrzymano w czterech przypadkach wynik korelujący z długością spoglądania na klawiaturę podczas produkcji tłumaczenia. Stąd wniosek, iż wśród osób badanych długość spoglądania na klawiaturę podczas pisania tekstu docelowego może wpływać na czas tłumaczenia ${ }^{8}$. Wyniki badań okulograficznych na większej grupie osób pomogą

\footnotetext{
${ }^{8} \mathrm{Na}$ podstawie grupy piętnastoosobowej oraz wyliczenia statystycznego (por. A. Bonek 2017) uzyskałam wynik świadczący o braku istotnie statystycznej korelacji pomiędzy długością spo-
} 
pomóc stwierdzić, czy wdrożenie kursów pisania bezwzrokowego wśród thumaczy może się przyczynić do przyśpieszenia procesu tłumaczenia.

\subsection{Optymalny uklad okien roboczych na monitorze}

W niniejszym punkcie zostaną przedstawione wyniki analizy materiału screen recording osób badanych, nagranych przez oprogramowanie okulograficzne, wraz ze ścieżką wzroku osób badnych podczas wykonywania tłumaczenia. Studenci zostali pouczeni o możliwości swobodnego przesuwania okien roboczych podczas tłumaczenia, a także zostali zachęceni do wygodnego dla nich ułożenia okien na monitorze. Celem tej części badania było sprawdzenie, jaki układ okien roboczych z uwzględnieniem ścieżki wzroku osób badanych umożliwi najmniejszą liczbę zbędnych przesunięć oraz sprawniejsze przeprowadzenie procesu tłumaczenia. Pytanie badawcze dotyczące układu okien roboczych na monitorze podczas pracy tłumacza zostało postawione przez E. Zwierzchoń-Grabowską (2011).

Szczegółowa analiza nagrań screen recording oraz ścieżek wzroku osób badanych umożliwiła wyciągnięcie wniosku dotyczącego rozkładu okien roboczych, który umożliwiał osobom badanym sprawne poruszanie się pomiędzy obszarami roboczymi oraz uniknięcie zbędnych operacji wykonywanych za pomocą myszki komputerowej. Poniżej znajduje się prezentacja przykładowego układu okien roboczych, wybranego przez kilka osób badanych.

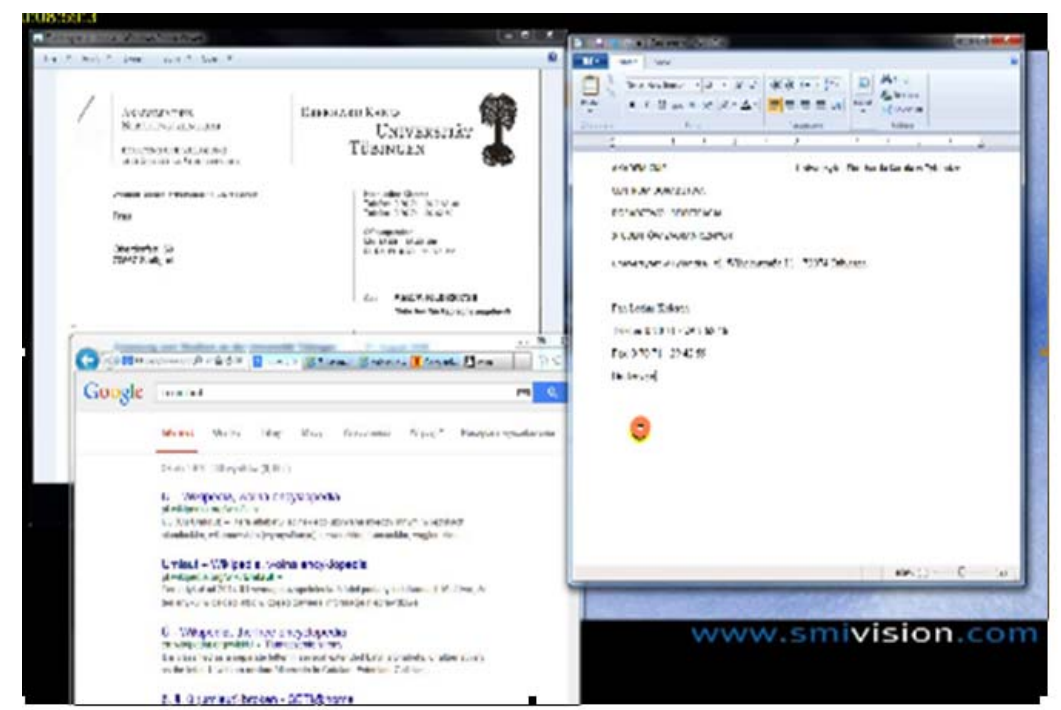

Rysunek 1. Optymalny uktad tekstu wyjściowego, tekstu docelowego oraz przegladarki internetowej podczas wykonywania thumaczenia.

glądania na klawiaturę podczas produkcji tekstu a czasem thumaczenia. Wynik dotyczy jednakże wyłącznie grupy badanej. W celu wyciągnięcia jednoznacznych wniosków w tym zakresie niezbędne są dalsze badania okulograficzne i statystyczne. 
Rysunek nr 1 prezentuje optymalny układ okien roboczych, który wypracowano na podstawie przeanalizowanych nagrań screen recording, ścieżek wzroku oraz kliknięć i przesunięć myszką wśród pięciu osób badanych" ${ }^{9}$. Powyższy układ tekstu wyjściowego, tekstu docelowego oraz przeglądarki internetowej potwierdza wnioski z pkt nr 1), który dowodzi, że największa praca kognitywna związana była z produkcją tekstu docelowego, stąd rysunek nr 1 ukazuje, że program edytorski prezentowany jest na ekranie w całości, zaś tekst wyjściowy oraz przeglądarka internetowa współdzielą lewą stronę monitora. Wydaje się, że prezentowany układ okien roboczych może ułatwić sposób poruszania się thumaczy pomiędzy trzema programami używanymi jednocześnie.

\subsection{Czas formatowania w tekście docelowym i czas thumaczenia.}

Podczas analizy nagrań screen recording oraz ruchów gałek ocznych osób badanych zauważono, że odzwierciedlenie formatowań tekstu wyjściowego w tekście docelowym jest czasochłonną częścią procesu thumaczenia. Przy tym osoby badane wybierały różne strategie formatowań tekstu docelowego. Osoby badane stosowały dwie strategie formatowań. Pierwsza grupa rozpoczynała formatowanie fragmentu tekstu docelowego natychmiast po zakończeniu jego thumaczenia na język polski, natomiast druga grupa rozpoczynała formatowanie tekstu docelowego dopiero po zakończeniu thumaczenia. Całkowity czas tłumaczenia w drugiej grupie był znacznie mniejszy niż w pierwszej. Osoby rozpoczynające formatowanie tekstu docelowego po zakończeniu thumaczenia szybciej ukończyły formatowanie, niż osoby, które dokonywały formatowania w trakcie tłumaczenia. Przyczyną tego stanu rzeczy było to, że nowy tekst, pojawiający się $\mathrm{w}$ trakcie thumaczenia $\mathrm{w}$ edytorze tekstu powodował przesunięcie się w edytorze już sformatowanych i przetłumaczonych fragmentów tekstu, co wymuszało na osobach badanych ponowne formatowanie tych samych fragmentów tekstu. Czas poświęcony formatowaniu oraz całkowity czas tłumaczenia zaprezentowano $\mathrm{w}$ poniższej tabeli.

\begin{tabular}{|c|c|c|c|c|}
\hline & A & B & A-B & A-B\% \\
\hline osoba & $\begin{array}{c}\text { Tluma- } \\
\text { czenie [s] }\end{array}$ & $\begin{array}{c}\text { Tluma- } \\
\text { czenie bez for- } \\
\text { matowania [s] }\end{array}$ & $\begin{array}{c}\text { Forma- } \\
\text { towania [s] }\end{array}$ & $\begin{array}{c}\text { Formato- } \\
\text { wania [\%] }\end{array}$ \\
\hline P01 & 2300 & 1772 & 528 & 22,9 \\
\hline P02 & 3745 & 3243 & 502 & 13 \\
\hline P03 & 3164 & 2258 & 906 & 28,6 \\
\hline P04 & 2297 & 1616 & 681 & 8,4 \\
\hline P05 & 1819 & 1666 & 153 & 8 \\
\hline
\end{tabular}

Tabela 4. Całkowity czas tłumaczenia oraz czas poświęcony formatowaniu tekstu docelowego.

W ostatniej kolumnie tabeli nr 4 ukazano wyliczony na podstawie danych zebranych przez okulograf czas wykonywania formatowania tekstu docelowego przedstawiony $\mathrm{w}$ wartościach procentowych. $\mathrm{Z}$ ostatniej kolumny wynika, że czas formatowania stanowi od 8 do $30 \%$ całkowitego czasu tłumaczenia. Nasuwa się wniosek, że

${ }^{9}$ Badania w grupie piętnastoosobowej w A. Bonek (2017) potwierdziły ten wniosek. 
w celu przyśpieszenia procesu thumaczenia, czas poświęcony formatowaniom tekstu powinien być skrócony. Aby tego dokonać niezbędne jest doskonalenie obsługi programu edytorskiego, a także rozpowszechnianie użycia programów dedykowanych dla thumaczy np. Across, który umożliwia przejęcie formatowań do tekstu docelowego jednym kliknięciem myszy. Sprawniejsza obsługa programów edytorskich powinna przyczynić się do ergonomizacja procesu thumaczenia pisemnego.

\subsection{Sposób wyszukiwania źródel internetowych w przeglądarce internetowej}

W niniejszym punkcie przedstawiony będzie przegląd źródeł elektronicznych wykorzystywanych przez osoby badane w czasie przygotowywania thumaczenia (tabela $\mathrm{nr}$ 5), a także zaprezentowany będzie sposób formułowania zapytań w przeglądarce internetowej google.pl (tabela $\mathrm{nr}$ 6). Uzyskane dane będą przeanalizowane pod kątem usprawnienia procesu wyszukiwania i obsługi przeglądarki internetowej.

\begin{tabular}{|l|l|}
\hline Źródła elektroniczne & Liczba zapytań \\
\hline Pons.eu & 13 \\
\hline Linguee.pl & 5 \\
\hline Pl.bab.la & 8 \\
\hline Ling.pl & 2 \\
\hline Glos.pl & 3 \\
\hline wikipedia & 3 \\
\hline wiktionary & 1 \\
\hline m.translator.pl & 1 \\
\hline Proz.pl & 5 \\
\hline Glosbe.pl & 4 \\
\hline Wiki.pl & 1 \\
\hline Pl.ozali & 1 \\
\hline Diki.pl & 1 \\
\hline Teksty paralelne & 2 \\
\hline
\end{tabular}

Tabela 5. Źródła internetowe używane w czasie tlumaczenia.

Analiza nagrań screen recording oraz ruchy gałek ocznych osób badanych wykazały, że studenci wpisywali wyszukiwane hasła w górny pasek wyszukiwania w przegląarce internetowej, zaś ścieżka wzroku osób badanych wykazała, że wybór dokonywali przeglądając zaledwie pierwsze trzy propozycje sugerowane przez wyszukiwarkę google. Wyniki zaprezentowane w tabeli nr 5 pokazują, że badani często korzystali z przypadkowych źródeł (duża liczba źródeł była wyświetlana zaledwie kilka razy). Powyższe wyniki świadczą o braku strategii w wyborze źródeł elektronicznych oraz o korzystaniu z przypadkowych źródeł zasugerowanych przez wyszukiwarkę google. Zaobserwowano konieczność korzystania z jednojęzycznych słowników, encyklopedii tematycznych, tekstów paralelnych, czy też korpusów językowych. Brak zainteresowania głębszym wyjaśnieniem tłumaczonego tekstu świadczyć może o braku wiedzy specjalistycznej niezbędnej dla porównania różnic pomiędzy polskimi i niemieckimi instytucjami prawnymi. Jednakże to właśnie wiedza specjalistyczna 
niezbędna jest dla tłumaczenia tekstów specjalistycznych. Ponadto tabela nr 5 ukazuje, że istnieje pilna potrzeba zdefiniowania zaufanych źródeł internetowych dla potrzeb studentów ${ }^{10}$, co umożliwiłoby nie tylko usprawnienie procesu tłumaczenia, ale także podniesienie jakości translatu.

Oprócz źródeł internetowych wykorzystywanych w czasie tłumaczenia w centrum zainteresowania znalazł się sposób formułowania wyszukiwanych haseł w przeglądarce internetowej. Poniższa tabela przedstawia, jakie dodatkowe uściślające wyrażenia były dodawane przez studentów, aby sprecyzować szukane zapytanie. W cudzysłowie podawane są wyrażenia, które były wpisywane wraz z szukanym hasłem.

\begin{tabular}{|l|c|}
\hline Rodzaj zapytania & Liczba zapytań \\
\hline Zapytanie w j. niemieckim & 20 \\
\hline Propozycje thumaczenia w j. polskim & 14 \\
\hline Zapytanie w j. niemieckim + ,po polsku” & 8 \\
\hline Zapytanie w j. niemieckim + ,słownik” & 3 \\
\hline Zapytanie w j. niemieckim + ,niemiecki” & 3 \\
\hline Zapytanie w j. polskim + ,po niemiecku” & 2 \\
\hline Zapytanie w języku niemieckim + słowa z kontekstu & \\
\hline
\end{tabular}

Tabela 6. Sposób formułowania zapytań w wyszukiwarce google.pl.

Analiza nagrań screen recording potwierdziła, że osoby badane wyszukiwały hasła nie zmieniając ustawień językowych oraz regionalnych przeglądarki google.pl, co mogło by w znaczny stopień usprawnić poszukiwanie haseł zwłaszcza tych, które były wyszukiwane w języku niemieckim. Zmiana ustawień regionalnych przeglądarki umożliwi szybsze odnalezienie sposobu posługiwania się danym wyrażeniem w kulturze wyjściowej lub docelowej. Zmiana ustawień językowych i regionalnych zmieni preferencje wyszukiwania i ułatwi odnalezienie poszukiwanej informacji, zwłaszcza, że osoby badane skupiały swój wzrok na pierwszych trzech hasłach proponowanych przez wyszukiwarkę. Umiejętne zarządzanie filtrami wyszukiwarki usprawni dotarcie do szukanego celu, pod warunkiem oczywiście, że zostanie uprzednio zdefiniowany. Wnioskując z danych uzyskanych w tabeli nr 6 wydaje się konieczne ustalenie strategii wyboru źródła internetowego oraz wykształcenie umiejętności definiowania celu, który towarzyszyć winien poszukiwaniom niezbędnych rozwiązań translacyjnych. Ponadto wyniki wyszukiwania wskazują na to, że osoby badane poszukiwały już gotowe tłumaczenie danego wyrażenia w tekstach dedykowanych od i dla thumaczy, takich jak teksty dwujęzyczne bądź fora tłumaczy. Otrzymane wyniki mogą okazać się również ciekawe w kontekście rozwoju pomocy elektronicznych dla tłumaczy oraz określenia potrzeb, a także luk wśród istniejących programów dla tłumaczy tekstów specjalistycznych.

\footnotetext{
${ }^{10}$ Lista polecanych źródeł elektronicznych została opublikowana na stronie Instytutu Tłumaczeń Ustnych i Pisemnych na Uniwersytecie im. Karla Ruprechta w Heidelbergu (http://www.uni-heidelberg.de/ fakultaeten/ neuphil/iask/ sued/seminar/ abteilungen/ russisch/russisch.html) [Pobrano 26.11.2016].
} 


\section{Podsumowanie}

Zebrane w wyniku badania okulograficznego dane umożliwiły określenie czynników wpływających na czas thumaczenia oraz jakość translatu. Wyniki przeprowadzonego badanie zasygnalizowały obszary możliwych badań okulograficznych w translatoryce oraz możliwości, jakie niesie ze sobą okulograf przy rekonstrukcji kompetencji translacyjnych. Uzyskane wyniki wykazały miejsca krytyczne w procesie thumaczenia oraz czynniki mogące spowolnić, a także przyśpieszyć proces tłumaczenia.

Usprawnienie procesu tłumaczenia można osiągnąć dzięki doskonaleniu umiejętności obsługi programów komputerowych, takich jak edytor tekstu, w którym powstaje tekst docelowy oraz ustawień zaawansowanych w przeglądarce internetowej. Kursy szybkiego pisania na klawiaturze ze szczególnym uwzględnieniem znaków szczególnych i liczb mogą pomóc skrócić proces thumaczenia, jednakże pozytywny wypływ pisania bezwzrokowego na proces thumaczenia nie został do tej pory stwierdzony w badaniach okulograficznych i wymaga dalszych badań (por. A. Bonek 2017).

Ponadto stwierdzona została konieczność dostosowania sposobu formułowania zapytań w przeglądarce internetowej oraz ustawień jej filtrów dla celów translacyjnych. Filtry wyszukiwarki muszą być ustawione w ten sposób, aby możliwie najpełniej odpowiadały naszemu celowi. Większe rozeznanie w zasobach źródeł internetowych oraz poznanie możliwości, jakie Internet oferuje tłumaczom, pomoże precyzyjniej formułować zapytania oraz umożliwi skuteczniejsze korzystanie z zasobów komputerowych oraz internetowych.

W tym zakresie dobrym rozwiązaniem mogą okazać się szkolenia pozwalające udoskonalić warsztat pracy tłumacza ze źródłami online. Powyższe umiejętności przyporządkować można „kompetencji komputerowej” tłumaczy, która stanowi nieodzowny element warsztatu pracy thumacza. Zdefiniowanie producenta tekstu wyjściowego i odbiorców tekstu docelowego oraz określenie, czy szukane hasło powinno się pojawić w kontekście kultury wyjściowej czy docelowej powinno pomóc szybciej dotrzeć do szukanego rozwiązania. Ponadto zachodzi potrzeba poszerzenia wiedzy specjalistycznej studentów tłumaczeń specjalistycznych w zakresie dziedziny, z której pochodzi tłumaczony tekst specjalistyczny, której braki uwidoczniły się na podstawie wykorzystywanych źródeł przez osoby badane.

Wypracowanie wiarygodnej i zaufanej listy źródeł internetowych oraz korzystanie z literatury pochodzącej z dziedziny specjalistycznej (teksty paralelne oraz encyklopedie specjalistyczne) powinno zminimalizować wystąpienie błędów merytorycznych w thumaczeniu.

\section{Bibliografia}

Bonek, A. (2017; w druku), Eyetracking-Analyse computergestützten Übersetzungsprozesses. Übersetzung deutschsprachiger Verwaltungsakte ins Polnische. Frankfurt/ M.

Chang, V.C.Y. (2011), Translation Directionality and the Revised Hierarchical Model: An Eye-Tracking Study, (w:) Sh. O'Brien (red.), Cognitive Explorations of Translation (Continuum Studies in Translation). London/ New York, 154-75. 
Göpferich, S. (2008), Translationsprozessforschung. Stand-Methoden-Perspektiven. Tübingen.

Grucza, S. (2011), Lingwistyka antropocentryczna a badania okulograficzne, (w:) Lingwistyka Stosowana/ Applied Linguistics/Angewandte Linguistik, 4, 149-162.

Grucza, S. (2013), Die Augen reden mächtiger als die Lippen. Eye-Tracking-,,Einblicke" in die Sprache, (w:) Zeitschrift des Verbandes Polnischer Germanisten/ Czasopismo Stowarzyszenia Germanistów Polskich, 2, 189-202. (www.ejournals.eu/ZVPG/Tom-2(2013)/Zeszyt_2_(2013)/ art/2647/; pobrano 22.12.2016).

Grucza, S. (2014), Grundzüge der anthropozentrischen Translatorik, (w:) A. ŁypBielecka (red.), Mehr als Worte. Sprachwissenschaftliche Studien. Professor Dr. habil. Czesława Schatte und Professor Dr. habil. Christoph Schatte gewidmet. Katowice, $127-137$.

Holmqvist, K./ M. Nyström/ R. Andersson/ R. Dewhurst/ H. Jarodzka/ J. Van de Weijer (2011), Eye Tracking - A Comprehensive Guide to Methods and Measures. Oxford.

Just, M.A./ P.A. Carpenter (1980), A Theory of Reading: From Eye Fixations to Comprehension, (w:) Psychological Review, 87 (4), 329-354.

Kilian, A./ A. Kilian (2009), Stownik języka prawniczego i ekonomicznego/ Wörterbuch der Rechts- und Wirtschaftssprache. Niemiecko-polski. Deutsch-polnisch. Tom I. Warszawa.

O’Brien, Sh. (2006), Eye-tracking and translation memory matches, (w:) Perspectives: Studies in Translatology, 14, 185-205.

Pavlović, N./ K.T.H. Jensen (2009), Eye tracking translation directionality, (w:) A. Pym/ A. Perekrestenko (red.), Translation Research Projects 2. Tarragona, 93109 (http://isg.urv.es/ publicity/isg/publications/ trp_2_2009/ index.htm; pobrano 24.11.2016).

Płużyczka, M. (2015), Tłumaczenie a vista. Rozważania teoretyczne i badania eyetrackingowe. Warszawa.

Sjørup, A.C. (2011), Cognitive Effort In Metaphor Translation: an Eye-Tracking Study, (w:) Sh. O'Brien (red.), Cognitive Explorations of Translation. London/ New York, 197-215.

Timarova, Š./ B. Dragsted/ G. Hansen (2011), Time lag in translation and interpreting: A methodological exploration, (w:) C. Alvstad/ A. Hild/ E. Tiselius (red.), Methods and Strategies of Process Research. Integrative approaches in Translation Studies. Amsterdam/ Philadelphia, 121-149.

Zwierzchoń-Grabowska, E. (2011), Okulograficzne wsparcie badań nad procesem tłumaczenia pisemnego, (w:) Lingwistyka Stosowana/ Applied Linguistics/ Angewandte Linguistik, 4, 199-210. 